\title{
The contribution of Andrew Taylor Still to medicine: 1986 Scott memorial lecture
}

PAUL E. KIMBERLY, D.O., FAAO, D.OSTED.(HON.) Seminole, Florida
The Scott Memorial Lecture Award came at an opportune time. Since the publication of the article, "What characterizes an osteopathic principle?: Selected responses to an open question,"1 there has been a nagging thought in my mind that the term osteopathic principles was being misused. It seemed that it was being confused with "osteopathic philosophy" and that the confusion could be reduced by a review of the old osteopathic literature, especially the books whose titles contained the word principle. It has been my contention that there are, in fact, no "osteopathic" principles, but there is a very clearly stated "osteopathic philosophy" that is well supported by basic science facts.

The goal of the Scott Memorial Lecture is to give to the present day students of osteopathy a glimpse of Dr. A.T. Still's principles and techniques especially emphasizing his careful and thoughtful approach. ${ }^{2}$ Thus the award has provided the stimulus for a bit of library research.

My review of over 30 books and pamphlets has not fully supported my contention, but it has revealed some historic information which has modified my understanding of the history, development, language, and application of osteopathic medicine. There is some unanimity in the literature suggesting that Still took three known principles, added another of his own, and molded them into the "philosophy of osteopathy." Probably his single most important contribution is that he applied the philosophy in the prevention and treatment of disease. The three principles discussed in historic medicine are:

(1.) The principle of body unity. This broad panoramic view of the human body, even though discussed through the centuries, was not applied in the diagnosis and treatment of disease.
(2.) The principle of vis medicatrix naturae - the healing power of nature-has been discussed in medical literature since the days of Hippocrates, but only in rare instances was it applied or considered in the treatment of disease. This concept is currently reflected in immunology, homeostasis, repair of damaged tissues, and compensation for irreparable damage. ${ }^{3}$

(3.) The principle of structure/function interrelationships has also been discussed in medical circles at the gross, chemical, and cellular levels but not applied in the therapeutic arena on a consistent basis. $^{3-5}$

The principle developed by Still is the concept that deranged soma will result in altered physiology and/or chemistry of related tissues. This change in the structure is identifiable by palpation and occasionally by observation. The scope of this derangement may be the complete restriction of an articulation or minor changes in the connective tissues. Its removal permits improved/normal function in local and/or systemic structures and thus gives relief to the patient from related subjective discomfort. This concept has been called by many names, some of which are: bony lesion, osteopathic spinal lesion, osteopathic structural lesion, osteopathic lesion, and osteopathic greater lesion complex. The current official name of this phenomenon is somatic dysfunction, which is defined as: "Impaired or altered function of related components of the somatic (body framework) system: skeletal, arthrodial, and myofascial structures, and related vascular, lymphatic, and neural elements." 6

The philosophy that evolved from this line of thinking is very simple and straightforward when applied to the diagnosis and treatment of disease 
and the maintenance of health. The theory is that any mechanical problem interferes in some way with the flow of fluids to and from an area. Also, the nervous system is involved either in the influence of fluid motion and/or in the function of related viscera, and/or in the manifestation of symptoms. These factors represent the structure/function and body unity principles mentioned above. The removal of the mechanical problem (somatic dysfunction) permits for the healing power of nature to manifest itself along with normalizing the structure/function changes at the cellular, tissue, and organ levels.

The welding together of these four principles that Still called osteopathy is the first, and so far only, philosophy of medicine. It is not only still applicable to the practice of general medicine, but it encompasses all of the specialty areas as well.

The goal of Andrew Taylor Still during the 1870s was to find a way to improve the patient management being used in contemporary medical practices. The insight resulting in osteopathy was only an unproven theory when he announced his philosophy in 1874 . However, during the next 18 years, his continuous study of anatomy and his diligent application of his philosophy to the multiple types of health problems presented to him resulted in such dramatic "cures" that he could not cope with the demand for services. In September of 1892, the State of Missouri granted a charter for the American School of Osteopathy whose stated purpose was "...To improve our systems of surgery, midwifery and treatment of diseases in general."

The primary goal of the training program was to create in the student such an understanding of normal anatomy and physiology (which included chemistry) that his examination of a patient would reveal the slightest deviation from normal. Also, this intimate knowledge of normal held by the student should dictate the procedure(s) necessary to return the tissues of their patients to their normal state. This system of palpatory diagnosis and manipulative treatment was the foundation on which the practice of osteopathy developed. A key phrase often used by Still was that disease is the normal response of a deranged soma and that the osteopath must be able to reason from the effect being manifest to find the cause that was/is often obscure. Treatment was to remove the cause, that is, to remove the obstruction to the free flow of fluids (arterial, venous, lymphatic, tissue, and neural) and allow the healing power of nature to function.

Surgery was used when indicated, the pregnant patient was treated with manipulation, and the basic concepts of nutrition and hygiene were taught and recommended to the patients when indicated. Osteopathy was not developed or taught as a "drugless" system of medicine. The dearth of effective drugs and the "miraculous" results of manipulation created the illusion of drugless healers. The anesthetics, antiseptics, and the analgesics needed for surgery and obstetrics were always a part of the osteopathic armamentarium.

Thus, the great contributions of Andrew Taylor Still to the maintenance of health and the prevention and treatment of disease are:

(1.) The pronouncement of a philosophy of medicine that stands alone in its viability after 100 years of successful application. He named his philosophy osteopathy. Its practitioners are called osteopathic physicians and their practice is called osteopathic medicine.

(2.) He made application of the principles of body unity, the healing power of nature, and the interrelationship of structure and function to the practice of medicine.

(3.) He likened the human body to a machine that is subject to multiple forms of misadjustment that can be identified and realigned by manual methods. The malalignment we identified above as somatic dysfunction; the realignment is called manipulative treatment.

New ideas are often ridiculed and, even when effective, are often slow to be absorbed into the mainstream of thought. The philosophy of osteopathy had even greater difficulty because of many statements which Still wrote in his books ${ }^{7-9}$ that, in the light of then current knowledge, were not only impossible but were colored by religious fervor and seeming clairvoyance.

I would like to "lift up" some of these descriptions, which seemed ridiculous to his contemporaries, to indicate that his understanding of human anatomy and physiology were 50 to 100 years ahead of his time.

(1.) "The rule of the artery and vein is universal in all living beings...." 10 "...a disturbed artery marked the beginning to an hour and a minute when disease began to sow its seeds of destruction in the human body."11 "The rule of the artery is absolute, universal, and it must be unobstructed, or disease will result." 12 The necessity for an ample supply of nutrients and a means to eliminate waste in the living organism is well known to the horticulturist and husbandman, but it is often neglected by the physician who seems to get sidetracked by symptoms and laboratory reports.

"All the processes of earth-life, must be kept in perpetual motion to cultivate and be kept in a healthy condition...."13 Guyton ${ }^{14}$ seems to support this concept by saying, "The extracellular fluid is in constant motion throughout the body and is rapidly mixed by the blood circulation and by diffusion between the blood and the tissue fluids."

When somatic dysfunction interferes with this motion of fluid, the physiology of the involved 
tissue changes and the signs and symptoms of disease manifest. Which is more logical, to treat the disease or to remove the cause which permitted the disease to develop?

(2.) "God's drug store." This reference often produces a laugh for those who act before they think. Two quotes from Still's autobiography supply the basis: "...that all the remedies necessary for health exist in the human body" 15 and "...I further proclaimed that the body of man was God's drug-store and had in it all liquids, drugs, lubricating oils, opiates, acids and anti-acids, and every sort of drug that the wisdom of God thought necessary for human happiness and health."16 Even in Still's time, the healing power of nature still required that at least some of this list be available. Acquired immunity requires the body to create the substances needed. Homeostasis requires a continuous adjustment of the body chemistry. The liver creates enzymes to remove or neutralize the nonfood chemicals such as food additives, preservatives, food coloring, artificial sweeteners, sprays, and pollutants, which cannot be directly eliminated by the kidneys, lungs, or skin. Substance P was discovered in the spinal cord associated with chronic pain. In more recent years, endogenous opioids found in the central nervous system are being studied. Thus, other areas in which his statements, apparently without basis at that time, are being supported by current scientific research.

(3.) Fascia the "hunting ground." The manner in which the term fascia is frequently used is too restrictive. According to Gray, “...fascia signifies little more than a collection of connective tissue large enough to be described by the unaided eye."17 Several quotations from Still's writings will indicate that he was "thinking" connective tissue and not just "fascia." In the Philosophy of Osteopathy we find these four statements: "...the fascia is the place to look for the cause of disease and the place to consult and begin the action of remedies in all diseases,..."; "But the fascia is the ground in which all causes of death do the destruction of life."; "The fascia gives one of, if not the greatest problems to solve as to the part it takes in life and death;" and, "By its (fascia) action we live, and by its failure we shrink, or swell, and die."18

For the person who thinks of fascia only as visible structural supports, these statements do not make sense. However, reading in modern textbooks such as Gray's Anatomy ${ }^{19}$ and Guyton's Physiology ${ }^{20}$ supplies information that not only supports the implications of the statements of Still, but explains how somatic dysfunction, even minor impairment at soft tissue levels, creates the milieu for cellular dysfunction and, ultimately, the symptoms and finally the signs of a disease process. The amorphous ground substance relationship to the movement of plasma protein and the development of lymph channels and their role as a part of the extracellular fluid mechanism which controls the nutrition to and waste from the parenchymal cell alone supports Still's statements. In addition, we find in the connective tissues the lubricant for smooth gliding of one tissue upon another and the first line of defense from any type of invasion from organisms or debris which enter through the skin.

(4.) The brain, nerves, and cerebrospinal fluid. During my training 50 years ago, the brain was a storage and coordination center. The nerves were solid cords whose function was equivalent to an electric wire. Cerebrospinal fluid was primarily a water cushion in which the brain was suspended. The fluid was produced in the choroid plexuses and exited through the arachnoid villae to the sagittal sinus. Before looking at some of the recent research, let us review certain statements which Dr. Still made in his turn-of-the-century writings.

(1.) "The brain...should be the most attractive for study. It is the place where all force centers, where all nerves connect to one common battery." 21 The great advances in the understanding of the brain and its physiology makes it much more than the "battery" to which Still referred. In some of the above material, we have suggested its manufacturing capabilities. Also, in the absence of lymphatics, the extracellular fluids including the amorphous ground substance escape through the cerebrospinal fluid. Some authors even suggest that cerebrospinal fluid escape may include regional veins and lymphatics in addition to the arachnoid villae.

(2.) Nerves. "....that all diseases are mere effects, the cause being a partial or complete failure of the nerves to properly conduct the fluids of life."22 "Nerves have five qualities, nutrition, sensation, motion, voluntary and involuntary." 23 The italics are added to call attention to what, even a few years ago, seemed such absurd statements by Still. Research performed during the decade of the $1960 \mathrm{~s}$ has demonstrated that the nerve is hollow and that neuronal proteins are transported to the muscle. Also, these substances cross the nerve muscle barrier and have a trophic effect upon the tissue supplied. ${ }^{24}$

(3.) Cerebrospinal fluid. Still said, "Turn the waters of life loose at the brain, remove all hindrances and the work will be done, and give us the eternal legacy, longevity." ${ }^{25} \mathrm{He}$ also stated, “...that the cerebro spinal fluid is the highest known element that is contained in the human body... and that this great river of life must be tapped and the withering field irrigated at once, or the harvest of health will be forever lost." 26 This statement has been quoted by the trainees of W.G. Sutherland, D.O., for the last 40 years, but no one has been able to make a direct 
connection between cerebrospinal fluid and the tissues outside the nervous system except via the usual venous and possibly lymphatic channels. However, the potential of a perineural outflow of cerebrospinal fluid has been a possibility in my mind since my early training with Sutherland. A research project attempted in 1948 was neutral in its revelation. ${ }^{27}$ However, two Canadian researchers working with animal models did demonstrate a perineural flow of cerebrospinal fluid along the full length of the axon and a dissemination into the tissues. ${ }^{28}$ Thus, what to me is the last of the socalled wild and impossible statements attributed to Still has been substantiated by modern research.

The only apology which we as osteopathic physicians need to make regarding Andrew Taylor Still and his writings and the philosophy which he called osteopathy is for those among us who have failed to apply the philosophy in daily patient care. The healing power of nature cannot fully function until somatic dysfunction in all of its forms has been removed. Yes, the patient may live, he may be free of symptoms, but does he have the level of health that we as osteopathic physicians are obligated to provide by virtue of our degree?

\section{Summary}

The plethora of definitions presented in the article, "What characterizes an osteopathic principle?"29 combined with selection to give the Scott Lecture Award created an opportunity to review the literature and to sort out the seemingly irrational interchange of principle and philosophy in the osteopathic literature and teaching. Mixed in with this were frequently used quotations which confused the issue.

The result of these efforts has greatly clarified my thinking. A principle is a fundamental truth. The literature indicates that Andrew Taylor Still took three principles which existed in the medical literature but had never been consistently applied in health care. To this he added a fourth, somatic dysfunction. One defintion of philosophy is, "...the body of principles or general conceptions underlying a given branch of learning or major discipline." ${ }^{30}$ Therefore, my conclusion is that Still took four principles, molded them into a philosophy called osteopathy and, of greatest importance, successfully applied this philosophy to patient care.

Dr. Still had some very unusual insights which some would call clairvoyance. He made statements about body functions that, to the best of my knowledge, have all been proven; the last one is the perineural outflow of cerebrospinal fluid published in $1968 .^{29}$

The contributions of Andrew Taylor Still to medi- cine are: (1.) The development of a philosophy of medicine which is the first and only in existence; and (2.) He applied the four principles of this philosophy to the prevention and treatment of disease along with patient education about nutrition and hygiene to create the only complete practice of medicine in existence today.

1. Sprafka, S., Ward, R.C., and Neff, D.: What characterizes an osteopathic principle? Selected responses to an open question. JAOA 81:29-33, Sep 81

2. American Academy of Osteopathy: Scott Memorial Lecture Award. In AAO Manual of Procedure. AOA, Newark, Ohio, 1982, p. 97

3. Wright, H.M.: Perspectives in osteopathic medicine. Kirksville College of Osteopathic Medicine, Kirksville, Mo., 1976, p. 8

4. Northup, G.W.: Osteopathic medicine: An American reformation American Osteopathic Association, Chicago, IIl., 1966

5. Page, L.E.: The principles of osteopathy. Academy of Applied Osteopathy. Kansas City, Mo., 1952

6. Glossary of osteopathic terminology. JAOA 80:552-66, Apr 81

7. Still, A.T.: Philosophy of osteopathy. Published by A.T. Still, Kirksville, Mo., 1899, p. 97

8. Still, A.T.: Autobiography. Rev. Ed. Published by A.T. Still, Kirksville, Mo., 1908

9. Still, A.T.: Osteopathy research and practice. Published by A.T. Still, Kirksville, Mo., 1910

10. Op. cit. ref. 7 , p. 153

11. Op. cit. ref. 8 , p. 182

12. Op. cit. ref. 8 , p. 182

13. Op. cit. ref. 7 , p. 180

14. Guyton, A.C.: Basic human physiology. Ed. 2. W.B. Saunders Co. Philadelphia, 1977 , p. 4

15. Op. cit. ref. 8 , p. 88

16. Op. cit. ref. 8, p. 182

17. Warwick, R., and Williams, P.L.: Gray's Anatomy. Ed. 35 (Brit.). Long man, London, 1973 , p. 490

18. Op. cit. ref. 7 , pp. 86,23 , and 164

19. Op. cit. ref. 17 , pp. $32-41$

20. Op. cit. ref. 14 , pp. $3-10$

21. Op. cit. ref. 7, p. 47

22. Op. cit. ref. 8, p. 94

23. Op. cit. ref. 7, p. 96

24. Korr, I.M. and Appeltauer, G.S.: The time-course of axonal transport of neuronal proteins to muscle. Exp Neurol 43:452-63, May 1974

25. Op. cit. ref. 7 , p. 79

26. Op. cit. ref. 7 , p. 39

27. Kimberly, P.E.: Implications of cerebrospinal fluid distribution in the therapy of the healing arts. Biol Bull V. 94 : No. 2, Oct 48

28. Steer, J.C., and Horney, F.D.: Evidence for passage of cerebrospinal fluid among spinal nerves. Canad Med Assoc J 98:71-4, 13 Jan 68 29. Op. cit. ref. 1

30. Webster's New International Dictionary. Unabridged. 1956, definition 2.B

Accepted for publication in January 1987.

Dr. Kimberly was the Stuenenberg professor and chairman, Department of Osteopathic Theory and Methods at the Kirksville College of Osteopathic Medicine. He also served as a clinical professor, Department of Biomechanics at Michigan State University College of Osteopathic Medicine.

Dr. Kimberly, 10901 Johnson Blvd., Apt. J609, Seminole, Florida 33542-6655. 


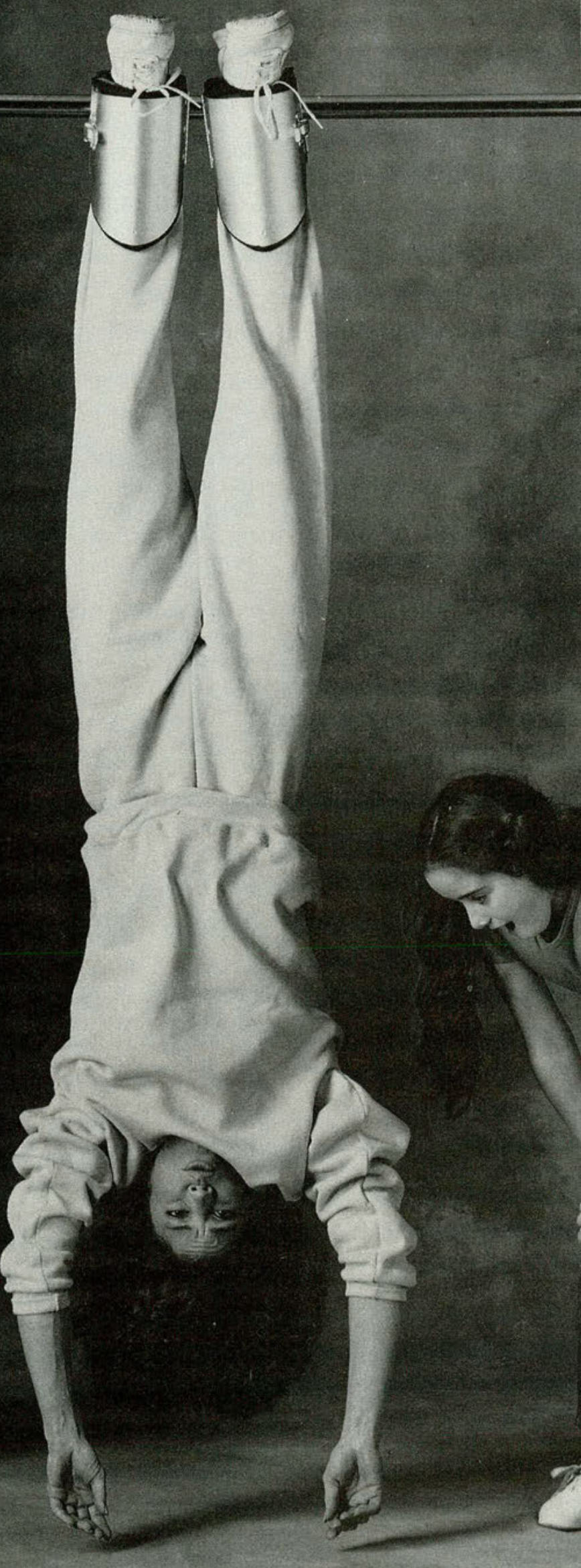

\section{Oh, the extremes people go to.}

Some people will go to any length to relieve back pain. Even if it means turning their world upside down.

Too bad she didn't come to you. Relief of painful musculoskeletal conditions can be so simple with Norflex ${ }^{\circledR}$ (orphenadrine citrate) - just one tablet b.i.d. Or one Norflex Injectable for on-the-spot relief.

Norflex effectively relieves pain and associated spasm. And it has a better safety profile - no sedation, ${ }^{*}$ no danger of habituation.

*Some patients may experience transient episodes of light-headedness, dizziness or syncope, which may impair their ability to engage in potentially hazardous activities such as operating machinery or driving a motor vehicle; ambulatory patients should therefore be cautioned accordingly.

\section{NORFLEX BIID.}

(orphenadrine citrate) $\begin{aligned} & \text { Sustained-Release } \\ & \text { Tablets }\end{aligned}$

\section{Relief pure and simple.}

Please see next page for full prescribing information. 


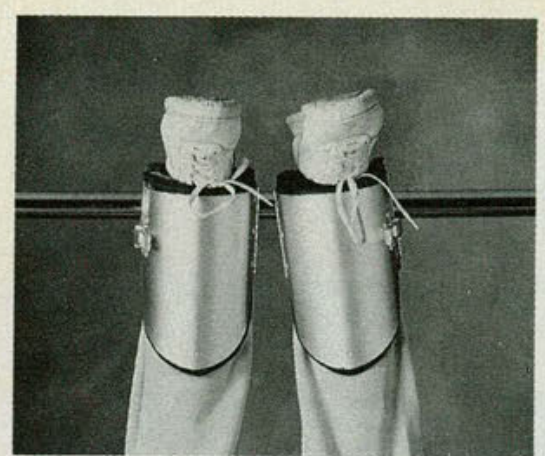

NORFLEX BI.D.

(orphenadrine citrate) TABLets and INUECTABLE

\section{Relief pure and simple.}

\section{Prescribing Information}

DESCRIPTION: Orphenadrine citrate is the citrate salt of orphenadrine (2-dimethylaminoethyl 2-methylbenzhydryl ether citrate) It occurs as a white crystalline powder having a bitter taste. It is practically odorless, sparingly soluble in water, slightly soluble in alcohol.

ACTiON. The mode of therapeutic action has not been clearly identified, but may be related to its analgesic properties. Orphenadrine citrate also possesses anticholinergic actions

WhiCATIONS: Orphenadrine citrate is indicated as an adjunct to rest physical therapy, and other measures for the relief of discomfort associthe the drug has not been clearly identiled, but may be relaled to its anaigesic properties. Orphenadi

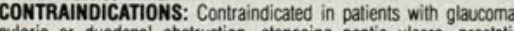
pyloric or duodenal obstruction, stenosing peptic ulcers, prostatic oder neck, cardiospasm (megaesophagus) and myasthenia oravis.

Contraindicated in patients who have demonstrated a previous hypersensitivity to the drug

WARNINGS: Some patients may experience transient episodes of lightheadedness, diziness or syncope. Norflex may impair the ability of the patient to engage in potentially hazardous activities such as operating machinery or driving a motor vehicle; ambulatory patients should therefore be cautioned accordingly. USAGE IN PREGNANCY: Sale use of orphenadrine has not been established with respect to adverse effects upon fetal development Therefore Norflex should be used in women of child earing potent and particularly during arly pregnancy only when in the judgment of the

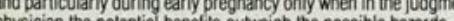

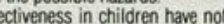
been established; therefore, this drug is not recommended for use in the pediatric age group

RECAUIONS: Contusion, anxiety and tremors have been reported in lew patients receiving propoxyphene and orphenadrine concomitantly As these symptoms may be simply due to an additive effect, reduction of dosage and/or discontinuation of one or both agents is recommended in such cases

Orphenadrine citrate should be used with caution in patients with tachycardia, cardiac decompensation, coronary insufficiency, cardiac arrhythmias.

Satety of continuous long-term therapy with orphenadrine has not been established. Therefore, if orphenadrine is prescribed for prolonged use, periodic monitoring of blood, urine and liver function values is recommended

ADVERSE REACTIONS: Adverse effects of orphenadrine are mainly due to the mild anticholinergic action of orphenadrine, and are usually associated with higher dosage. Dryness of the mouth is usually the first adverse effect to appear. When the daily dose is increased possible adverse effects include: tachycardia pa pitation urinary hesitancy or retention, blurred vision, dilation of pupils, increased ocular tension, weakness, nausea, vomiting headache, dizziness, constipation, drowsiness, hypersensitivity reactions, pruritus, hallucinations, agita tion, tremoc, gastric irritation, and rarely urticaria and other dermatoses. Infrequently an elderly patient may experience some degree of menta confusion. These adverse reactions can usually be eliminated by reduction in dosage. Very rare cases of aplastic anemia associated with the use of orphenadrine tablets have been reported. No causal relationship has been established.

Rare instances of anaphylactic reaction have been reported associated with the intramuscular injection of Norflex injectable

DOSAGE AND ADMINISTRATION: TABLETS: Adults-Two tablets per day. one in the morning and one in the evening.

INUECTABLE: Adults - One $2 \mathrm{ml}$, ampul ( $60 \mathrm{mg}$ ) intravenously or intramuscularly may be repeated every 12 hours. Relief may be main tained by 1 Norflex tablet twice daily

HOW SUPPLIED: TABLETS: Bottles of 100 (NDC 0089-0221-10) and 500 (NDC 0089-0221-50), each tablet containing $100 \mathrm{mg}$ of of phenadrine citrate.

INJECTABLE: Boxes of 6 (NDC 0089-0540-06) and 50 (NDC 0089 . 0540-50) $2 \mathrm{~mL}$ ampuls, each ampul containing $60 \mathrm{mg}$. of orphenadrine citrate in aqueous solution, made isotonic with sodium chloride. A.M.ES. Calegory 12.08 CAUTION: Federal law prohibits dispensing without prescription.

\section{New members}

Biscotti, Louis J., CCOM '71; 2332 Bonnie Brae, Claremont, CA 91711

Chiumento, Nicholas P., PCOM ' 81 ; 4004 Birney Ave., Moosic, PA 18507

Coleman, Michael H., UHSCOM '77; 128 Parson Street, Easton, PA 18042

Daly, Michael J., Maj., UOMHS ' 80 ; 10th Medical Lab, APO, New York, NY 09180

Deacon, Dennis, MSU '79; 2236 Packard Rd., Ypsilanti, MI 48197

Dean, John D., UOMHS ' 66 ; 2514 14th Ave., Kingsburg, CA 93631-1102

Golden, Richard F., Capt., UOMHS '84; 2904 Arnold Blvd., Wichita, KS 67210

Hix, Elliott L., Jr., KCOM '80; 901 Poplar, Kirksville, MO 63501

Keller, Michael G., TCOM '78; 2030 Pulliam, San Angelo, TX 76905

Lentz, Rodney D., KCOM '74; 2105 Independence Blvd., Kansas
City, MO 64124

Nause, Charles L., Jr., UHSCOM ' 83 ; 3675 Hedrick St., Jacksonville, FL 32205

Patterson, Walter, WVSOM ' 79 ; Suite 403, 635 "C" St., San Diego, CA 92101

Price, Marla J., MSUCOM ' $84 ; 1776$ Stanford, Berkley, MI 48072

Propst, Arthur H., TCOM '76; Box 469, Erin, TN 37061

Rosenthal, Murray H., PCOM '77; Suite C, 2710 Health Center Dr., San Diego, CA 92123

Rostek, Barry, UOMHS '80; Apt. 5, 2632 Fillmore St., San Francisco, CA 94115

Spike, Joel Z., KCOM '71; Suite 202, 951 N. E. 167th St., North Miami Beach, FL 33162

Turner, Timothy T., KCCOS ' $73 ; 273$ Pennington Ln., Chesterfield, MO 63017

Walsh, Richard W., COMS '73; Box 4246, Muskegon Heights, MI 49444 


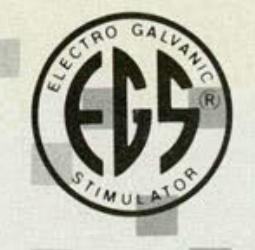

HIGH VOLTAGE PULSED GALVANIC STIMULATOR

(17. CII

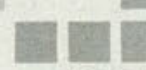

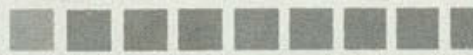

불

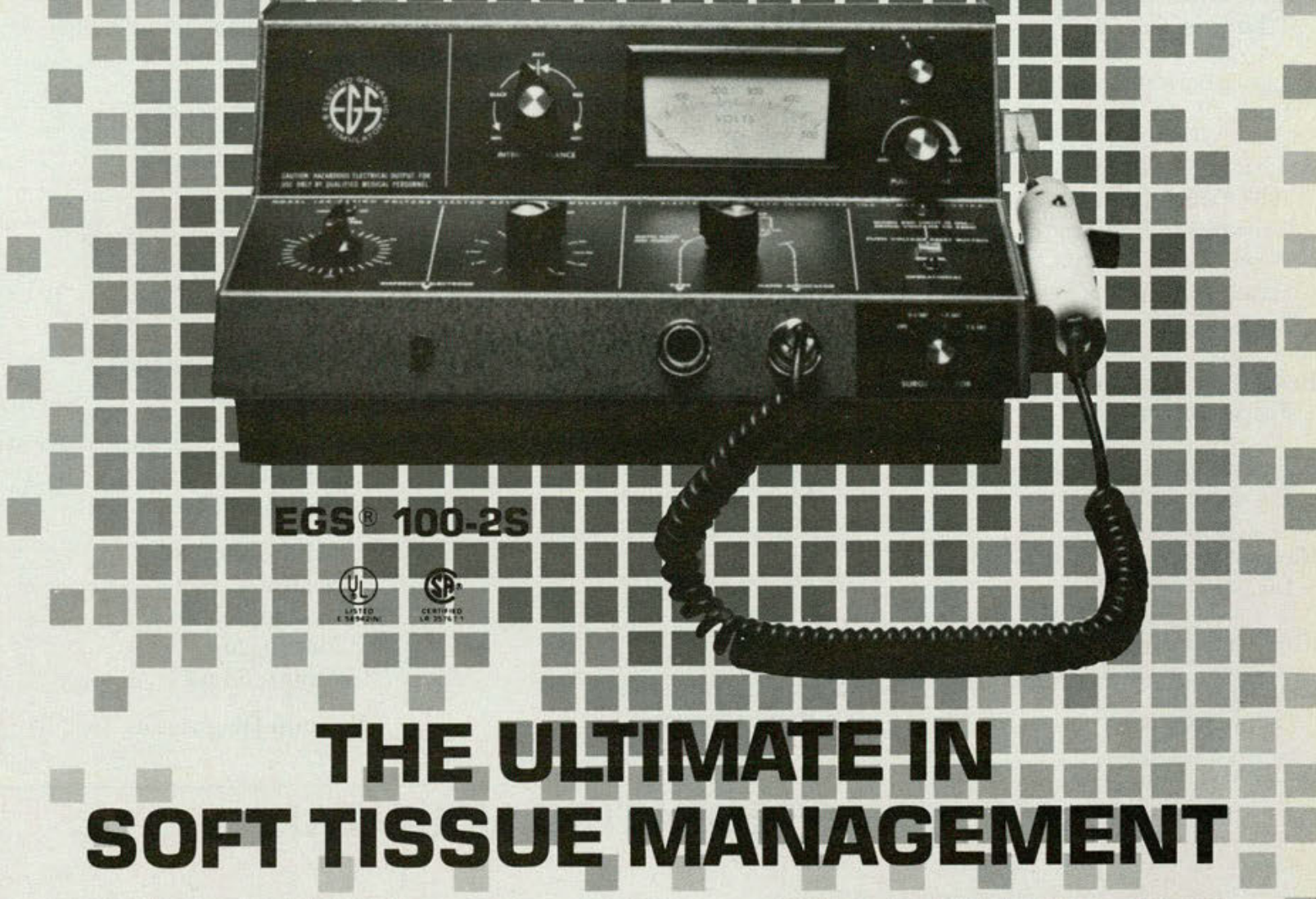

- Relieve spasticity and spasms (i.e. TMJ dysfunction)

- Increase local blood flow

- Delay atrophy from disuse in partially denervated muscle

- Re-educate muscle as in regaining joint control

- Stimulate calf post-operatively to prevent phlebothrombosis

- Relieve pain (EGS 300 only) when applied as a TENS

- Reduction of edema

- Totally safe

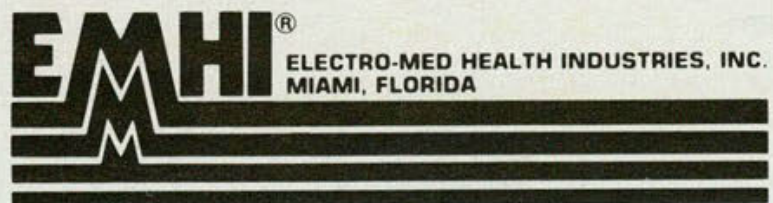

${ }^{-}$Manufacturers of Electro-Medical/Dental Equipment

6240 N.E. 4th Court $\cdot$ Miami, Florida 33138-6106 Phone: (305) 756-6013, Telex: 152303 EMHI UT

CAUTION: FEDERAL LAW RESTRICTS THIS DEVICE TO SALE BY OR ON THE ORDER OF A LICENSED PRACTITIONER

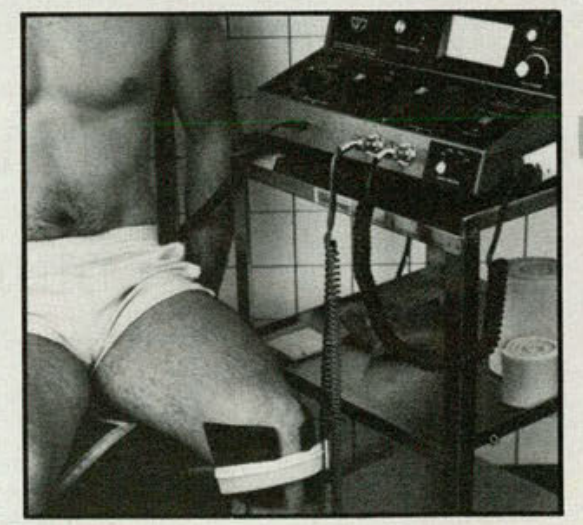

For more information clip and mail to:

ELECTRO-MED HEALTH INDUSTRIES, INC. 6240 N.E. 4th Court • Miami. Florida 33138

Name

Bus. Phone

Address

City

State Zip 
Abbott Laboratories

Tranxene, 37,38

Adria Laboratories, Inc.

Kaon CL-10, 3, 4

American Osteopathic Association 1987 Convention, 72

Convention Registration

Form, 73, 74

Hotel Convention Registration

Form, 75, 76

Beecham Laboratories

Fastin, 32-34

Ciba Pharmaceuticals

Estraderm, 79-82

Electro-Med Health Industries, Inc., 117

Flint Osteopathic Hospital, 118

Glenwood, Inc.

Calphosan, 3
Key Pharmaceuticals Nitro-Dur II, 12-14

Lever Brothers, Inc. Dove Bar, 11

Marion Laboratories Cardizem, 59-62

Merck Sharp \& Dohme Vaseretic, $39-43$

Merrell Dow Pharmaceutical, Inc. Seldane, $17-20$

Muro Pharmaceutical Inc. Guaifed, 55, 56

Pfizer Laboratories

Diabinese, 28-30

Minipress, 24-26

Riker Laboratories Disalcid, 35, 36

Norflex, 115, 116

Roche Laboratories Bumex, Cover 2-1
Roche Products Inc.

Valium, 44,45

Roerig

Glucotrol, 46-48

Ross Laboratories Isomil, 2

Sandoz Pharmaceuticals Tavist, 49, 50

Schein Inc., Henry, 77

Schering Laboratories Normodyne, 6-8

Smith Kline \& French Laboratories Dyazide, 64

Tagamet, Cover 4

Upjohn Company

Medrol, Cover 3

Micronase, 68-70

Motrin, 15

Xanax, 52-54

Vitamin Diagnostics, Inc., 57

\section{FLINT OSTEOPATHIC HOSPITAL}

\section{EXPANDING INTERNAL MEDICINE RESIDENCY PROGRAMS}

\section{FIRST, SECOND, THIRD YEAR POSITIONS AVAILABLE}

\section{BEGINNING JULY 1987}

Other Residency Programs

\section{ANESTHESIA}

ENT

General Practice

GASTROENTEROLOGY

Internal Medicine

OBSTETRICS

OPHTHALMOLOGY

ORTHOPEDICS

PATHOLOGY

PULMONARY

RADIOLOGY

SURGERY

UROLOGY

SUBSPECIALTY RESIDENCIES

GASTROENTEROLOGY

PULMONARY

\author{
Educational Programs \\ Daily Guest Lecturers \\ Monthly Seminars \\ MoRning REPORTS \\ JOURNAL CLUBS
}

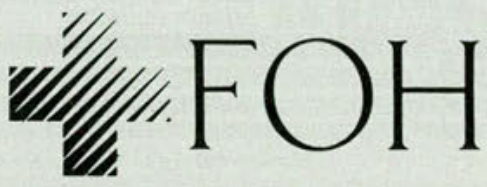

TO OBTAIN AN APPLICATION OR MORE INFORMATION ABOUT OUR PROGRAMS, CONTACT:

Flint Osteopathic Hospital Director of MEdical Education 3921 BEECHER ROAD

FLINT, Michigan 48502 (313) $762-4707$ 